\title{
The Use of Primary Documents on Literature History in Primary School
}

\author{
G Gunansyah \\ Universitas Negeri Surabaya \\ Surabaya, Indonesia
}

\author{
N D Novayanti \\ Universitas Negeri Surabaya \\ Surabaya, Indonesia
}

\begin{abstract}
This study aimed to determine the effect of the use of primary documents against the literacy of the students of the 5th grade Al-Azhar Mojokerto Islamic Plus Primary School. This research used Quasi Experimental Design research design in the form of Nonequivalent Control Group Design with instrument test. Data analysis technique used was t-test. The results showed that there was significant influence of the use of primary documents to the historical literacy of students as evidenced by hypothetical t-test count 5,626> ttable 2.030 . Through historical literacy, students are facilitated to be skilled at reading, writing, expressing views through various sources (photos, pictures, articles, newspapers, maps, videos, textbooks, documents / records / archives and non-documents such as architecture. Students not just become passive recipients or merely remember historical facts but they are actively involved in interpreting it, so they obtain complete understanding of the cause-effect (chronology) of a historical event.
\end{abstract}

Keywords: Primary Document; literature History; Primary School

\section{INTRODUCTION}

Literacy reading ability in the Program for International Student Assessment positioned Indonesia in the 64th rank with a score of 396 from an average score of 496 (OECD, 2013). Bickford (2013) indicates that elementary school teachers who have a good understanding of the relevance and urgency of social studies as well as interdisciplinary teaching have started regularly using the history-based children's textbooks that apply in the school curriculum [4]. In teaching history, teachers are expected to find curricular materials appropriate to the age of students, facilitate writing, choose a new topic, utilizing various texts of information both oral histories, current news articles, and artwork, anecdotes and suggested questions based on inquiry which encourages students to review the understanding of the text from the information presented [4].

Zahroh [13] affirms the learning of historical literacy to make students have a critical attitude of understanding, using, and reflecting on written text on history, in order to develop knowledge and potential, and to participate in society. Ahonen [1] considers that historical literacy is a behavior that demonstrates the mastery of information on the basis of history, which makes it possible to read and discuss history. Bennett (2014) describes historical literacy as the ability to read, write, and create historical views from primary and secondary sources, where historical literacy is one of the sub categories of literary discipline.

The purpose of this study is to know how much influence of the use of historical relics like primary documents can provide experience in everyday learning in the classroom. Through historical literacy, students are expected to be facilitated in reading, writing, expressing views through various primary sources such as photographs, pictures, articles, newspapers, maps, videos, textbooks, documents and non-documents such as architecture. Students can in turn be actively involved in interpreting historical events and gain a complete understanding of the basic concepts of events, chronology, changes and sustainability of historical events.

\section{METHOD}

This research used Quasi Experimental Design [14] using Non-equivalent Control Group Design research design [15]. The research location was at SD Islam Plus Al-Azhar Mojokerto, Indonesia with samples were 56 students from V-A and V-B classes. The data obtained through the test sheet by data analysis using testing $\mathrm{T}$-test hypothesis through the calculation of SPSS 22 .

\section{RESULTS AND DISCUSSION}

The data which is obtained from the average value of pretest and posttest on the contraction class and the experimental class as shown in Table I.

TABLE I. SCORE AVERANGE PRE-TEST AND POST-TEST

\begin{tabular}{ccc}
\hline Class & Average & \\
& Pretest & Posttest \\
\hline Control & 61,1 & 74,63 \\
Experiment & 64,72 & 85,39 \\
\hline
\end{tabular}


In table I, students' literacy skills indicate an increase between pretest and posttest results. The comparison of pretest and posttest results can be shown in Fig 1.

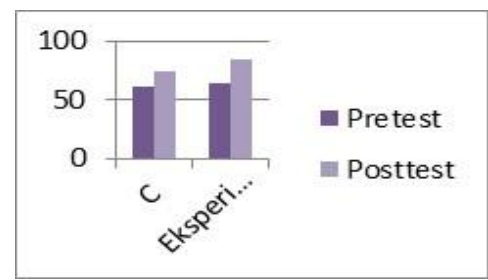

Fig. 1. Comparison pre-test and post-test result

Hypothesis testing using t-test to prove the hypothesis if there is influence of the use of primary documents to the literacy history of students of grade V SD Islam Plus Al-Azhar Mojokerto. The t-test is used to compare posttest results between control and experiment classes. In this study the t-test test is independent samples t-test using SPSS 22.

Based on the calculation results proved that there is influence of the use of primary documents given to the experimental class. It can be known by comparing t count with $\mathrm{t}$ table. With the provision of $\mathrm{H} \_0$ not proven if $\mathrm{t}$ count $>\mathrm{t}$ table, then the hypothesis "The influence of the use of primary documents to the literacy history of students of grade V SD Islam Plus Al Azhar Mojokerto" is accepted. The t table value can be seen in the statistics table with degrees of freedom (df) $=\mathrm{n}-2$ or $37-2=35$ then obtained ttable of 2.030 . From the calculation results, it is obtained t count of 5.626. Then it can be known t count 5.626> ttable 2.030. So, it can be concluded that H_0 is not proven and hence the hypothesis "The influence of the use of primary documents against the literacy of the students of grade V SD Islam Plus Al-Azhar Mojokerto" is accepted.

Normalized n-gain test $(\mathrm{g})$ is used to find out how the increase student's literacy history before and after learning using primary documents. Normalized n-gain test results can be seen from the following table.

TABLE II. NORMALIZED GIAN TEST

\begin{tabular}{ccccc}
\hline Class & Mean & $\begin{array}{c}\text { N-Gain } \\
\text { Prestest }\end{array}$ & Posttest & Category \\
\hline Control & 61,1 & 74,63 & 0,28 & Low \\
Experiment & 64,72 & 85,39 & 0,57 & Medium \\
\hline
\end{tabular}

From Table II shows that there is an increase in student history literacy in the control class as well as the experimental class. In the control class the gain value is 0.28 . This indicates the increase in student literacy is in the low category while in the experimental class the gain value is 0.57 . This indicates that the increase of students' literacy history is in the medium category. It proves that the use of primary documents has a positive impact and students' historical literacy. The literature of history is the ability to read, write, and create historical views from the primary and secondary sources. The literature of history allows students to be independent in building their opinions about the past based on historical evidence.

Other findings indicate the interest of students in learning using primary documents, i.e. : students can know the moral message when Bung Tomo speech video is displayed. Through a brief discussion and question and answer session on the sidelines of the activity of primary documents, students appear to be active and courageous to ask questions or express their opinions about the material being submitted. Even some students were showing admiration for the youthful spirit of the youth of Surabaya on the Battle of November 10, 1945 in Surabaya. Bennett et al (2014) corroborates historical texts such as primary sources and secondary sources providing the context for students to learn critical reading skills such as comparing and high-level thinking.

The use of primary documents is performed at each meeting where each of the primary document meetings that are presented contain some important related events. At each meeting, the researcher conducted question and answer session with the students verbally and asked them to discuss based on the worksheet in groups about the historical literacy on the material of the Battle of November 10, 1945 in Surabaya. It is intended to know the students' understanding of the material presented. When the students do the worksheet, the response given by the students is they seemed enthusiastically and actively discussing with their group.

One way to meet the demands of students against historical literacy is to take advantage of historic objects around. In improving the responses and interests of learners to the history lesson is done by creating patterns of learning related to environmental situations such as the use of historical relics such as primary documents. In line with that, Sandwell (2008) mentions the use of primary documents as a medium of learning is able to increase the literacy of student history.

The use of primary documents in achieving historical literacy results allows students to be active in building their opinions about the past based on historical evidence. Nokes (2011) asserts that historical literacy for high school and elementary students allows them to build opinions about the past. Martell (2013) argues that students should not only be passive recipients of historical facts, but also learn history through active engagement in interpreting history.

It is known that the utilization of primary documents in Social Studies learning especially historical material proved to be able to broaden students' thinking beyond the reading provided in the textbook which provided by the school. Sandwell [10] argues that primary documents work well when they are able to add value to existing sources (textbooks) in at least two ways: (1) improving content knowledge: adding value to textbooks and other resources By modeling, extending, or even opposing key facts in textbooks, (2) engaging students: drawing students into topics being discussed.

Based on the analysis, it is obtained some benefits for both teachers and students, they are (1) assist teachers in delivering 
the materials to students, (2) facilitate teachers in describing the historical situation that occurred at that time, thus making students have a direct picture of historical events in which so far students only know through a material to be memorized only. While the students are: (1) more interested in listening to the explanations given by the teacher, (2) helping students in interpreting history based on the primary documents they observe or listen to, (3) engaging in learning activities of historical material.

The use of primary documents in historical material learning activities is very flexible. For teachers or other researchers who will use primary documents in learning or research activities can make modifications by adjusting the material to be taught with the primary documents in accordance with the material. Based on these findings it is known that the use of primary documents in learning activities has advantages over learning activities without the use of primary documents. Nevertheless, some obstacles encountered are not all subject matter especially history can use the primary documents in accordance with historical material to be taught, its use takes a considerable time, especially for the preparation and delivery.

\section{CONCLUSION}

This study was conducted to test the utilization of cinema therapy to improve the counselor's understanding of the importance of students' sense dealing skills. The results show that the counselor has understood the nature of the skill of dealing the student's feelings and can train students' sensedealing skills. Just to raise the feeling of using tailored to the condition of the school. For schools that are able to show new videos have been able to recognize feelings, have not been able to distinguish the accompanying body reactions when negative feelings arise, choose how to express old feelings using new videos but some are using video, music or real experiences. Based on the measurements of conditions between before and after training are: Before treating the counselor is able to recognize the feelings that emerge well, not able to distinguish the body's reaction that accompanies when negative feelings arise and can choose how to express old feelings. After treatment counselors are able to recognize emerging feelings, the bias distinguishes the accompanying body reactions when negative feelings arise and can choose how to express a better feeling in the right situation.
Basically, dealing with feelings can be learned and trained to everyone through intensive training, especially through school training programs (Hallahan \& Kauffman, 1991). The results showed that the skills training to deal the feelings with experiential learning-based training methods proved to develop the skills to manage feelings.

\section{REFERENCES}

[1] S Ahonen, "Historical consciousness: a viable paradigm for history education?", in Journal of Curriculum Studies, Vol. 37 No. 6, pp 697-707, 2005

[2] S M Bennett, "Teachers' beliefs and implementation of historical literacy pedagogy in three Advanced Placement United States History classrooms"

[3] S M Bennett, J Stepp-Sanders, C D Gilewski, M L Nunn, H H Pinter, A Wenzel \& M Caskey, "Association for Middle Level Education', in Writing, Vol. 1 No. 2, p 3

[4] J H Bickford, "Initiating historical thinking in elementary schools", in Social Studies Research and Practice, Vol 60, 2013

[5] J H Bickford III \& M S Bickford, "Historical Thinking, Reading, and Writing about the World's Newest Nation, South Sudan”, in Social Studies Research and Practice, Vol. 111, 2015

[6] C C Martell, "Learning to teach history as interpretation: A longitudinal study of beginning teachers", in The Journal of Social Studies Research, Vol. 37 No. 1, pp 17-31, 2013

[7] J D Nokes, "Historical literacy. Social Studies: Newsletter of the Utah State Office of Education", Vol. 6, 2011

[8] O Pisa, Results: Executive Summary, 2009

[9] O Pisa, "Pisa 2009 results: Executive Summary", 2010. Accessible on webpage: http://www. oecd. org/pisa/pisaproducts/46619703. pdf Retrieved, 12(09), 2014

[10] R Sandwell, "Using primary documents in social studies and history", in The Anthology of Social Studies, Vol. 2, pp 295-307, 2008

[11] M J Schleppegrell, S Greer \& S Taylor, "Literacy in history: Language and meaning", in Australian Journal of Language and Literacy, The, Vol. 31 No. 2, p 174, 2008

[12] C E Snow, Reading comprehension: Reading for learning, 2010

[13] N L Zahroh, PEMANFAATAN SITUS SINGOSARI DALAM MENGEMBANGKAN LITERASI SEJARAH PESERTA DIDIK Penelitian Kualitatif Naturalistik di SMP Islam Al-Maarif 01Kecamatan Singosari Kabupaten Malang (Doctoral dissertation, Universitas Pendidikan Indonesia), 2012

[14] D C Thomas, "Quasi-Experimental Design", in Organizational Behavior, Vol. 11, p 2

[15] E B Cottrel, "Experimental and Quasi-Experitamtal Design", in ERIC, 1962 